\title{
PERUBAHAN DISTRIBUSI MERKURI (Hg) TERHADAP WAKTU DI SEDIMEN SUNGAI POBOYA
}

\author{
I. Febrianti ${ }^{1}$, R. Ratianingsih², dan J. W. Puspita ${ }^{3}$ \\ 1,2,3 Program Studi Matematika Jurusan Matematika \\ Fakultas Matematika dan IImu Pengetahuan Alam Universitas Tadulako \\ Jalan Sukarno-Hatta Km. 9 Palu 94118, Indonesia \\ 1igafebrianti@yahoo.co.id, 2ratianingsih@yahoo.com, 3juni.wpuspita@yahoo.com
}

\begin{abstract}
Poboya is illegal gold mining area at Palu City. The amalgamate process of gold extraction is prepared traditionally using mercury. Tailing of this process which contains mercury is throwed away to the ground. The mercury contain will infiltrate to the soil water and later on pollute Poboya's river. Related to the mercury that categorized as dangerous material, this research purposes to investigate the mercury distribution changing at Poboya's river sediment. The mercury distribution changing is investigated by modify the advection-diffusion equation model. The model was completed by the initial conditions and Neumann boundary conditions. To get the numerical solutions, it is used a numerical scheme namely Duffort Franke/finite difference method for the second derivative, and Center Scheme for the first derivative. The solution represents the mercury distribution changing with respect to time at the Poboya's river sediment. The simulation result explains that $0,0521 \mathrm{ppm}$ mercury is distributed from the upper bound (current source) observation domain following the sediment direction (to estuary) caused by the advection process and decreased due to the diffusion process. For $t=20$, the mecury was distributed $0,00285 \mathrm{~m}$ to the estuary direction with the mercury concentration is $0,005 \mathrm{ppm}$, until $t=200$, mercury was distributed $0,00832 \mathrm{~m}$ to estuary with mercury concentration is $0,005 \mathrm{ppm}$. In fact that at the estuary (lower bound), the 0,0244 ppm mercury that was already deposited will be diffused in an opposite direction. The advection process and the low initial mercury concentration, makes the reached distribution distance is no longer far comparing to the opposited mercury distribution. For $t=20$ the mercury was distributed $0,000822 \mathrm{~m}$ to the upper direction with mercury concentration is $0,005 \mathrm{ppm}$, until $t=200$, the mercury was distributed $0,000873 \mathrm{~m}$ with mercury concentration is $0,005 \mathrm{ppm}$.
\end{abstract}

Keywords : Advection-Diffusion, Finite Difference Method, Mercury, Poboya's River.

\section{ABSTRAK}

Poboya merupakan kawasan pertambangan emas ilegal yang ada di Kota Palu. Proses pengolahan emas di kawasan ini dilakukan secara tradisional menggunakan bahan merkuri melalui proses amalgamasi. Tailing dari proses tersebut yang masih mengandung merkuri dibuang ke tanah di sekitar kawasan pertambangan, yang kemudian terbawa oleh rembesan air tanah dan mencemari Sungai Poboya. Mengingat merkuri dikategorikan sebagai zat berbahaya, penelitian ini bertujuan untuk mengkaji perubahan distribusi merkuri terhadap waktu di sedimen Sungai Poboya. Perubahan distribusi merkuri terhadap waktu melalui media sedimen dikaji melalui modifikasi model yang direpresentasikan oleh persamaan adveksi-difusi. Modifikasimodel tersebut dilengkapi 
dengan syarat awal dan syarat batas Neumann. Untuk mendapatkan solusi numerik, digunakan metode beda hingga Duffort Frankel untuk turunan kedua, dan Centered Scheme untuk turunan pertama. Solusi tersebut menggambarkan perubahan distribusi merkuri terhadap waktu di sedimen Sungai Poboya. Hasil simulasi memperlihatkan bahwa seiring dengan perubahan waktu, merkuri sebesar 0,0521 ppm terdistribusi dari batas atas (sumber aliran) domain pengamatan mengikuti arah aliran sedimen (kearah muara) karena proses adveksi dan semakin berkurang seiring aliran sedimen karena proses difusi. Pada $t=20$ merkuri sudah terdeposisi sejauh $0,00285 \mathrm{~m}$ kearah muara dengan konsentrasi merkuri sebesar $0,005 \mathrm{ppm}$, hingga pada $t=200$ merkuri sudah terdeposisi sejauh 0,00832 $\mathrm{m}$ kearah muara dengan konsentrasi merkuri sebesar 0,005 ppm. Mengingat di muara sungai (batas bawah) sudah terdapat kandungan merkuri sebesar 0,0244 ppm, maka terdapat pula aliran merkuri kearah hulu karena proses difusi. Namun karena adanya proses adveksi dan konsentrasi merkuri awalnya rendah, membuat jarak distribusi merkuri yang dicapai akibat proses difusi tidak sejauh yang dicapai distribusi merkuri dari sumber aliran. Pada $t=20$ oleh proses difusi, merkuri sudah terdeposisi sejauh 0,000822 $\mathrm{m}$ kearah hulu dengan konsentrasi merkuri sebesar $0,005 \mathrm{ppm}$, hingga pada $t=200$ merkuri sudah terdeposisi sejauh 0,000873 m kearah hulu dengan konsentrasi merkuri sebesar 0,005 ppm.

\section{Kata kunci : Adveksi-Difusi, Merkuri, Metode Beda Hingga, Sungai Poboya.}

\section{PENDAHULUAN}

\subsection{Latar Belakang}

Air merupakan kebutuhan primer makhluk hidup. Tanpa air makhluk hidup akan mati. Bagi manusia, air digunakan hampir di setiap aktifitas sehari-hari, misalnya makan, minum, berkebun, bertani, mandi, mencuci, dan juga dibutuhkan manusia dalam skala besar, misalnya dalam perindustrian.Air yang dibutuhkan tentulah air yang memenuhi standar kelayakan.Banyak standar yang ditetapkan sesuai dengan peruntukannya.Namun yang jelas air tersebut harus bersih, bebas dari mikroba berbahaya, dan bebas polutan.Hanya kurang dari 1 persen air bersih di bumi yang dapat dikonsumsi makhluk hidup (Harian Kompas, 2016).Salah satu penyebab menurunnya kualitas air adalah pencemaran lingkungan akibat aktivitas industri pertambangan logam berat.Menurut Herman (2006) salah satu limbah yang dihasilkan oleh aktivitas penambangan logam berat adalah merkuri. Limbah ini terlepas ke lingkungan pada proses amalgamasi maupun pencucian, sehingga menyebabkan pencemaran air, tanah, maupun udara.

Poboya merupakan kawasan pertambangan emas ilegalyang menggunakan merkuri yang ada di Kota Palu. Hasil penelitian Purnawan dkk (2013) menunjukan bahwa konsentrasi merkuridalam sedimen di sekitar muara Sungai Poboya berkisar antara 0,0103 mg/kg-0,185 $\mathrm{mg} / \mathrm{kg}$. Nilai tersebut masih berada di bawah ambang batas yang ditetapkan oleh US EPA, yaitu $0,2 \mathrm{mg} / \mathrm{kg}$. Nilai konsentrasi tersebut diambil dari sedimen yang berasal dari lima titik, dimana dua diantaranya berada di Sungai Poboya.Meskipun konsentrasi yang didapatkan tidak melebihi ambang batas, namun dalam keadaan sistem yang tidak steady, serta merkuri yang masuk ke sungai secara kontinu, konsentrasi merkuri dapat bertambah seiring 
perubahan waktu. Oleh karena itu penelitian ini dilakukan untuk mengetahui perubahan distribusi merkuriterhadap waktu di sedimen Sungai Poboya.

Penelitian ini menggunakan metode numerik beda hingga yang diterapkan pada model distribusi merkuri, yaitu model Adveksi-Difusi. Model tersebut dapat merepresentasikan distribusi merkuri atau aliran perpindahan merkuri akibat perbedaan konsentrasi (Difusi) dan aliran sungai (Adveksi) pada setiap perubahan waktu. Adapun metode numerik yang digunakan adalah metode beda hingga dengan skema beda pusat (centered scheme) pada turunan pertama dari model pembangunnya dan skema Duffort Frankel (Duffort Frankel scheme) pada turunan keduanya.

\subsection{Asumsi Penelitian}

Beberapa asumsi dalam penelitian ini antara lain:

1. Sumber polutan menghasilkan material secara kontinu.

2. Topografi dasar sungai rata.

3. Sungai dianggap simetri, sehingga daerah yang dikaji adalah setengah domain penelitian.

4. Transport merkuri secara Adveksi-Difusi.

5. Arah aliran air sungai adalah homogen searah vertikal (kearah muara sungai), dan kecepatan rata-rata aliran sungai tidak berubah.

6. Transformasi kimia dan fisika sistem tidak diperhitungkan.

7. Polutan mengalami peristiwa difusi dalam arah vertikal (kearah muara sungai) maupun horizontal dengan koefisien difusi tetap.

8. Awalnya merkuri berada di sedimen sungai dengan tidak ada perubahan konsentrasi terhadap waktu.

9. Nilai konsentrasi polutan pada batas atas dan bawah sama di setiap titik.

10. Perubahan suhu tidak diperhitungkan.

\subsection{Batasan Penelitian}

1. Penerapan model Adveksi-Difusi terbatas pada merkuri dalam sedimen sungai.

2. Sumber merkuriadalah rembesan air tanah yang mengandung merkuri.

3. Domain pengamatan adalah Sungai Poboya, Kota Palu. Dari lokasi titik $\bar{A}$ sampai lokasi titik $\bar{B}$ yang berjarak $300 \mathrm{~m}$.

4. Data parameter diperoleh dari penelitian terkait sebelumnya.

5. Data konsentrasi merkuri diperoleh dari penelitian terkait sebelumnya. 


\section{METODE PENELITIAN}

Penelitian ini dilakukan sesuai prosedur penelitian berikut:

1. Penelitian dimulai dengan studi pustaka, yaitu mempelajari bahan yang akan dijadikan sebagai penelitian.

2. Identifikasi masalah, yaitu menetapkan masalah yang akan di angkat sebagai penelitian.

3. Pengambilan data, dilakukan untuk memenuhi kebutuhan penelitian, yang selanjutnya diolah.

4. Mengolah data yang didapat untuk digunakan dalam penelitian.

5. Memodifikasi persamaan Adveksi-Difusi sesuai asumsi-asumsi penelitian.

6. Menentukan skema beda hingga, yaitu model numerik dari persamaan modifikasi PDP Adveksi-Difusi.

7. Menentukan nilai awal dan syarat batas, sesuai dengan data yang diperoleh dari penelitian sebelumnya dan asumsi penelitian.

8. Menginput parameter, yaitu koefisien Difusi Merkuri $(D)$, dan kecepatan aliran sungai $(U)$ yang didapatkan dari penelitian-penelitian sebelumnya.

9. Menentukan $\Delta x, \Delta y, \Delta t$ yang memenuhi syarat kekonvergenan skema beda.

10. Mensimulasikan pola distribusike program yang di buat dalam software Matlab R2010a untuk mempermudah perhitungan.

11. Menganalisis hasil simulasi.

12. Menyimpulkan hasil simulasi.

III. HASIL DAN PEMBAHASAN

\subsection{Modifikasi Model Adveksi-Difusi}

Untuk mendapatkan model transport merkuri yang dapat merepresentasikan transport merkuri di sedimen Sungai Poboya, bentuk umum model adveksi-difusi $\frac{\partial C}{\partial t}=-U\left(\frac{\partial C}{\partial x}+\frac{\partial C}{\partial y}+\right.$ $\left.\frac{\partial C}{\partial z}\right)+D\left(\frac{\partial^{2} C}{\partial x^{2}}+\frac{\partial^{2} C}{\partial y^{2}}+\frac{\partial^{2} C}{\partial z^{2}}\right)$ (Mosey, 2011) dimodifikasi sesuai asumsi sebagai berikut:

1. Karakteristik arah aliran sungai homogen searah sumbu vertikal $\left(U \frac{\partial C}{\partial y}=0\right.$ dan $U \frac{\partial C}{\partial z}=$ $0)$, sehingga diperoleh,

$$
\frac{\partial C}{\partial t}=-U \frac{\partial C}{\partial x}+D\left(\frac{\partial^{2} C}{\partial x^{2}}+\frac{\partial^{2} C}{\partial y^{2}}+\frac{\partial^{2} C}{\partial z^{2}}\right)
$$

2. Penelitian diamati pada kasus Ground Level $(z=0)$ dengan kedalaman konstan $\left(D \frac{\partial^{2} C}{\partial z^{2}}=0\right)$, sehinggadari persamaan (1) diperoleh,

$$
\frac{\partial C}{\partial t}=-U \frac{\partial C}{\partial x}+D\left(\frac{\partial^{2} C}{\partial x^{2}}+\frac{\partial^{2} C}{\partial y^{2}}\right)
$$




\subsection{Menentukan Skema Beda Hingga}

\subsubsection{Skema Beda Hingga}

Model transport merkuri pada persamaan (2) selanjutnya didiskritisasi sehingga dengan menggunakan metode beda hingga berikut:

$\frac{\partial C}{\partial t}=\frac{C_{i, j}^{n+1}-C_{i, j}^{n-1}}{2 \Delta t}, \frac{\partial C}{\partial x}=\frac{C_{i+1, j}^{n}-C_{i-1, j}^{n}}{2 \Delta x}, \frac{\partial^{2} C}{\partial x^{2}}=\frac{C_{i+1, j}^{n}-C_{i, j}^{n+1}-C_{i, j}^{n-1}+C_{i-1, j}^{n}}{\Delta x^{2}}$, dan $\frac{\partial^{2} C}{\partial y^{2}}=$ $\frac{C_{i, j+1}^{n}-C_{i, j}^{n+1}-C_{i, j}^{n-1}+C_{i, j-1}^{n}}{\Delta y^{2}}$, dihasilkan skema numerik sebagai berikut:

$C_{i, j}^{n+1}=\alpha C_{i, j}^{n-1}+\beta C_{i+1, j}^{n}+\gamma C_{i-1, j}^{n}+\theta C_{i, j+1}^{n}+\theta C_{i, j-1}^{n}$

(Alman et. al., 2013)

\subsubsection{Nilai Awal dan Syarat Batas}

Dalam penelitian ini diasumsikan bahwa merkuri pada awalnya berada pada sepanjang sumber aliran. Masalah nilai awal dan syarat batas dari persamaan Adveksi Difusi dua dimensi yang digambarkan dalam persamaan (2) diselesaikan dengan skema beda hingga dalam persamaan (3). Untuk syarat awal (initial conditions) sebagai berikut:

$C^{\prime}(x, y, 0)=\frac{\partial C}{\partial t}=0,0 \leq x \leq k, 0 \leq y \leq l$
$C^{\prime}(x, y, 1)=\frac{\partial C}{\partial t}=0,0 \leq x \leq k, 0 \leq y \leq l$

sehingga,

$\frac{C_{i, j}^{1}-C_{i, j}^{-1}}{2 \Delta t}=0$, maka $C_{i, j}^{1}=C_{i, j}^{-1}$,

$\frac{C_{i, j}^{2}-C_{i, j}^{0}}{2 \Delta t}=0$, maka $C_{i, j}^{2}=C_{i, j}^{0}$,

Sehingga untuk kondisi (4) skemanumerik pada persamaan memberikan:

$C_{i, j}^{1}=\alpha C_{i, j}^{-1}+\beta C_{i+1, j}^{0}+\gamma C_{i-1, j}^{0}+\theta C_{i, j+1}^{0}+\theta C_{i, j-1}^{0}$

$C_{i, j}^{1}-\alpha C_{i, j}^{-1}=\beta C_{i+1, j}^{0}+\gamma C_{i-1, j}^{0}+\theta C_{i, j+1}^{0}+\theta C_{i, j-1}^{0}$

$(1-\alpha) C_{i, j}^{1}=\beta C_{i+1, j}^{0}+\gamma C_{i-1, j}^{0}+\theta C_{i, j+1}^{0}+\theta C_{i, j-1}^{0}$

$C_{i, j}^{1}=\frac{\beta C_{i+1, j}^{0}+\gamma C_{i-1, j}^{0}+\theta C_{i, j+1}^{0}+\theta C_{i, j-1}^{0}}{(1-\alpha)}$

dan untuk kondisi (5) skema numerik pada persamaan memberikan:

$C_{i, j}^{2}=\alpha C_{i, j}^{0}+\beta C_{i+1, j}^{1}+\gamma C_{i-1, j}^{1}+\theta C_{i, j+1}^{1}+\theta C_{i, j-1}^{1}$

$C_{i, j}^{2}-\alpha C_{i, j}^{0}=\beta C_{i+1, j}^{1}+\gamma C_{i-1, j}^{1}+\theta C_{i, j+1}^{1}+\theta C_{i, j-1}^{1}$

$(1-\alpha) C_{i, j}^{2}=\beta C_{i+1, j}^{1}+\gamma C_{i-1, j}^{1}+\theta C_{i, j+1}^{1}+\theta C_{i, j-1}^{1}$

$C_{i, j}^{2}=\frac{\beta C_{i+1, j}^{1}+\gamma C_{i-1, j}^{1}+\theta C_{i, j+1}^{1}+\theta C_{i, j-1}^{1}}{(1-\alpha)}$

Masalah syarat batas (boundary condition)proses adveksi-difusi dinyatakan sebagai berikut:

Syarat Batas Atas:

$C(0, y, t)=0,0521, \quad 0 \leq y \leq l, 1<t \leq m$

Syarat Batas Bawah:

$C(k, y, t)=0,0244, \quad 0 \leq y \leq l, 1<t \leq m$ 
Syarat Batas Kanan:

$C^{\prime}(x, l, t)=\frac{\partial C}{\partial y}=0, \quad 1 \leq x \leq k-1,1<t \leq m$

Dengan menerapkan Center Difference pada PDP (12) diperoleh:

$\frac{C_{i, l+1}^{n}-C_{i, l-1}^{n}}{2 \Delta y}=0 \leftrightarrow C_{i, l+1}^{n}=C_{i, l-1}^{n}$

Syarat Batas Kiri:

$C^{\prime}(x, 0, t)=\frac{\partial C}{\partial y}=0, \quad 1 \leq x \leq k-1,1<t \leq m$

Dengan menerapkan Center Difference pada PDP (14) diperoleh:

$\frac{C_{i, 0+1}^{n}-C_{i, 0-1}^{n}}{2 \Delta y}=0 \leftrightarrow C_{i, 1}^{n}=C_{i,-1}^{n}$

Nilai-nilai batas seperti pada persamaan (13) dan (15) digunakan untuk menghitung konsentrasi di daerah batas domain. Sedangkan untuk menghitung nilai konsentrasi merkuri dalam daerah domain digunakan persamaan beda hingga (3) dengan mensubtitusikan nilainilai parameternya.

\subsection{Parameter Penelitian}

Untuk mendapatkan perubahan distribusi merkuri terhadap waktu di sedimen Sungai poboya, digunakan parameter difusi $\left(D_{H g}\right)$ yang dihitung menggunakan persamaan $D_{H g}\left[m^{2} s^{-1}\right]=\frac{0.02293 \times e\left(\frac{17.76 \times 1000}{8.314 \times T_{w}}\right)}{10.000}=0,002469827 \mathrm{~m}^{2} \mathrm{~s}^{-1}$ (Fantozzi et. al., 2013).Dengan $T_{w}$ adalah temperatur air dalam Kelvin, dimana $T_{c}=32,8^{\circ} \mathrm{C}$ (Purnawan, 2013), sehingga $T_{w}=$ $\left(32,8^{\circ} \mathrm{C}+273.15\right)^{\circ} \mathrm{K}=305.23^{\circ} \mathrm{K}$.Sedangkan nilai $U=4.051 \mathrm{~m} / \mathrm{s}$ (Habibi, 2010).

\subsection{Simulasi Perubahan Distribusi Merkuri(Hg) di Sedimen Sungai Poboya}

Domain penelitian dipandang sebagai persegi panjang berukuran panjang $(P)=$ $300 \mathrm{~m}$, lebar $(L)=2 \mathrm{~m}$ dengan $t=0.001 \mathrm{~s}$. Dipilih $\Delta x=0.001, \Delta y=0.2$, dan $\Delta t=0.000005$. Sehingga banyaknya pias di $x, y, t$ berturut-turut $k=\frac{P}{\Delta x}=300.000$ pias, $l=\frac{L}{\Delta y}=10$ pias, dan $m=\frac{t}{\Delta t}=1000$ pias. Pembagian grid dalam domain pengamatan diilustrasikan pada Gambar 3.1 . 


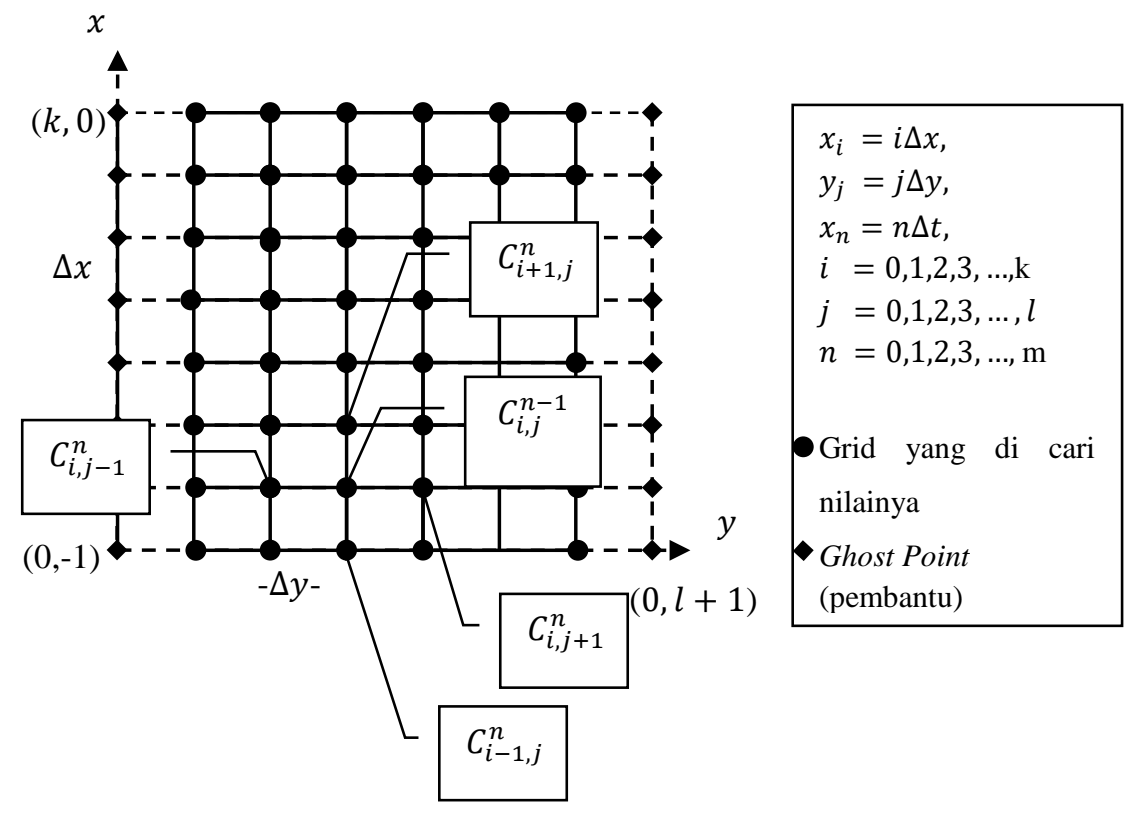

Gambar 1 : Domain Pengamatan

Gambar 1 memperlihatkandiskritisasi domain penelitian yang ditentukan berdasarkan data. Pada gambar tersebut diperlihatkan bahwa untuk mendapatkan nilai konsentrasi merkuri pada titik $C_{i, j}^{n+1}$, diperlukan nilai konsentrasi dari titik $C_{i, j}^{n-1}, C_{i+1, j}^{n}, C_{i-1, j}^{n}, C_{i, j+1}^{n}$, dan $C_{i, j-1}^{n}$.

Dengan $i=300.000$ pias, $j=10$ pias, dan $k=200$ pias maka program Matlab harus menghitung sebanyak 600.000 .000 solusi. Hal ini menyebabkan program tidak dapat dijalankan. Sehingga perlu dilakukan pemotongan pada domain pengamatan yang diilustrasikan pada Gambar 2.

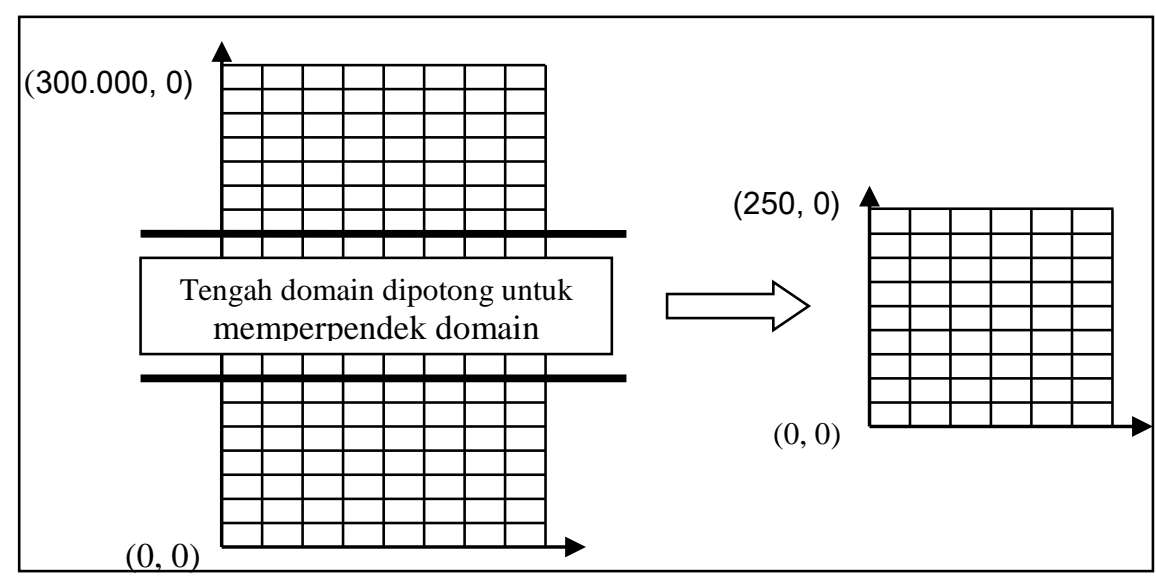

Gambar 2 : Transformasi Domain Pengamatan 
Gambar 3 memperlihatkan simulasi perubahan distribusi merkuri $(\mathrm{Hg})$ terhadap waktu di sedimen Sungai Poboya pada kondisi yang telah ditentukan dengan perbedaan waktu per $100 \times 10^{-6}$ sekon menggunakan program yang dibuat dalam software Matlab R2010a.Kemudian dianalisa terhadap rentang waktu per $20\left(5 \times 10^{-6}\right) \mathrm{s}$, dari $t=20(5 \times$ $\left.10^{-6}\right) \mathrm{s}$ hingga $t=200\left(5 \times 10^{-6}\right) \mathrm{s}$. Pada awalnya merkuri berada pada batas atas domain pengamatan (sumber aliran) dan batas bawah domain pengamatan. Setelah $t=20$ (Gambar 3.3.a) polutan dari sumber aliran sudah tersebar kedalam daerah aliran dengan nilai konsentrasi polutan maksimum 0,0521 sejauh 0,0028501 m kearah muara, dan pada batas bawahnya merkuri terdistribusi sejauh $0,0008216 \mathrm{~m}$ kearah hulu.Merkuri terdistribusi mengikuti arah aliran sedimen dan juga berlawanan arah aliran sedimen, hal ini terjadi karena selain mengalami proses adveksi serta difusi kearah horizontal, polutan juga mengalami proses difusi kearah vertikal. Hal tersebut dapat dilihat pada Tabel 2 bahwa pada sumber aliran, merkuri terdistribusi kearah muara sungai, sedangkan pada batas bawah domain pengamatan, konsentrasi merkuri terdistribusi berlawanan arah aliran air. Namun proses adveksi lebih kuat dari proses difusinya, sehingga pergerakan mengikuti arah aliran sedimen lebih kuat. Hal tersebut juga dapat dilihat pada Tabel 2. Konsentrasi merkuri yang paling tinggi berada di batas atasnya yaitu 0,0521 ppm dan semakin berkurang seiring arah aliran sedimen. Hal tersebut dapat dilihat dalam Gambar 3. Dalam jangka waktu yang lama, sistem akan menjadi steady(tidak ada perubahan konsentrasi merkuri di sedimen terhadap waktu).

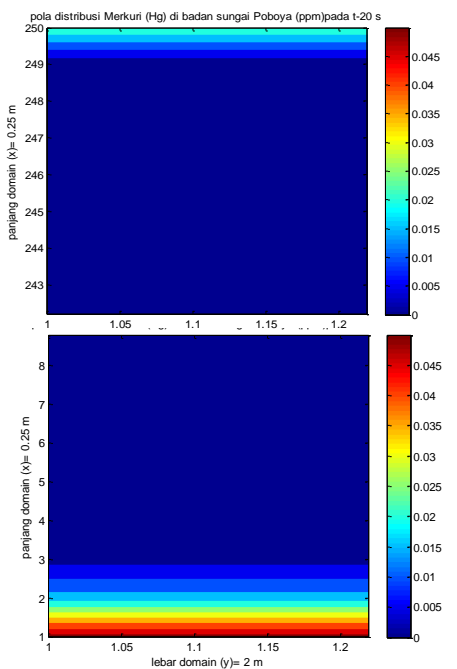

(a) Pada saat $t=20\left(5 \times 10^{-6}\right) \mathrm{s}$

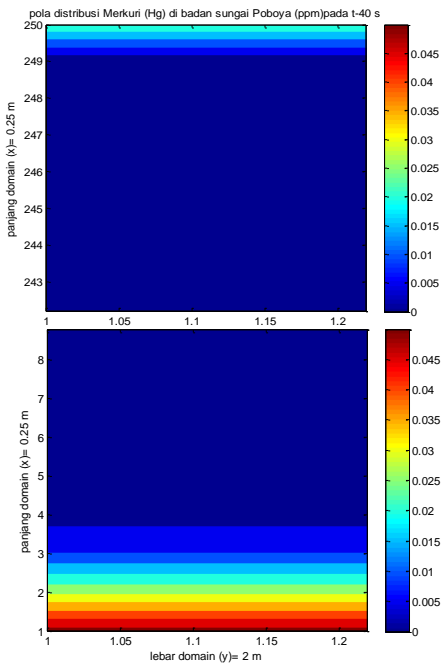

(b) Pada saat $t=40\left(5 \times 10^{-6}\right) \mathrm{s}$ 

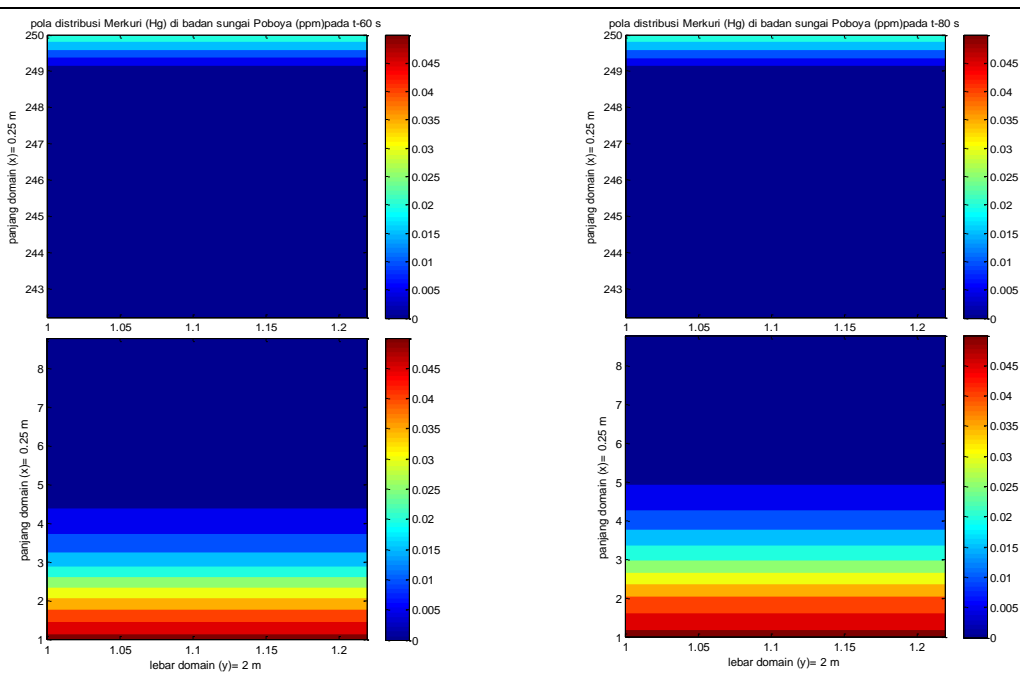

(c) Pada saat $t=60\left(5 \times 10^{-6}\right) \mathrm{s}$

(d) Pada saat $t=80\left(5 \times 10^{-6}\right) \mathrm{s}$
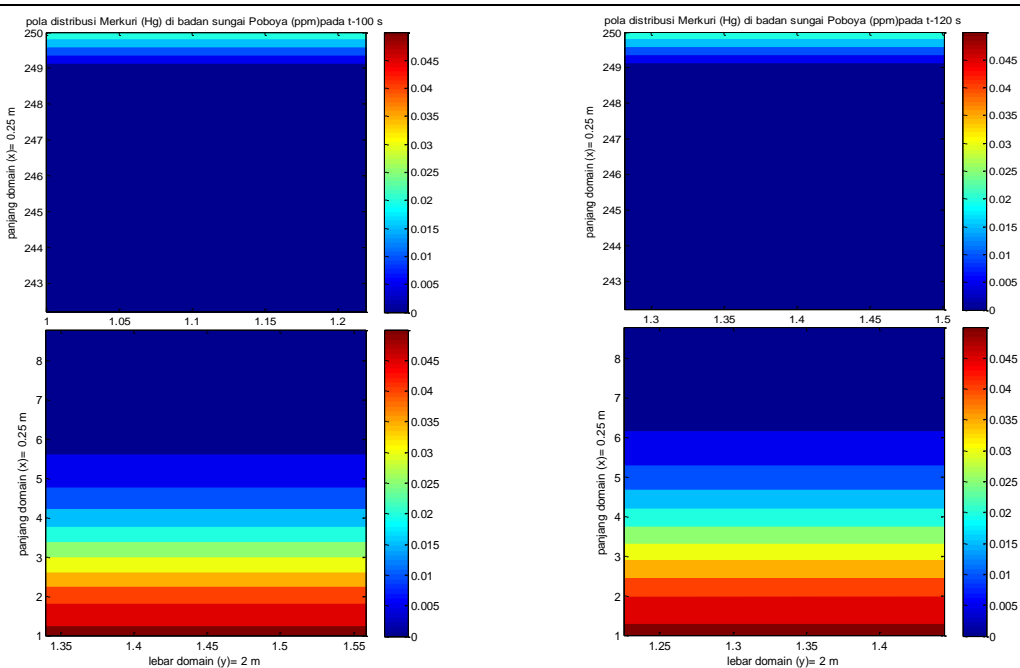

(e) Pada saat $t=100\left(5 \times 10^{-6}\right) \mathrm{s}$ (f) Pada saat $t=120\left(5 \times 10^{-6}\right) \mathrm{s}$
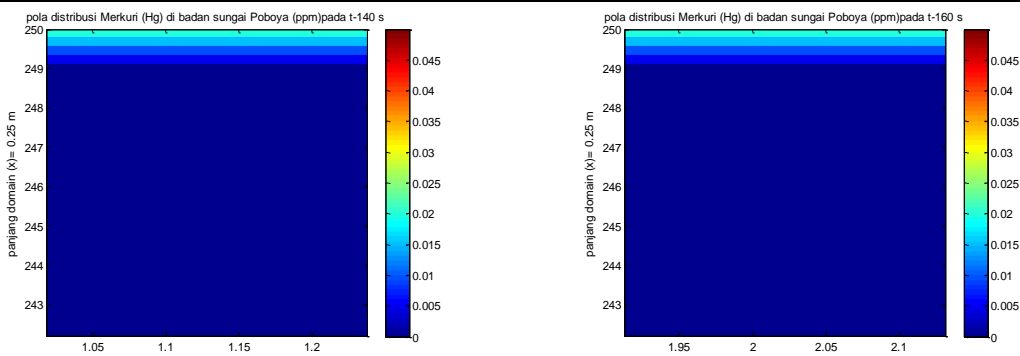


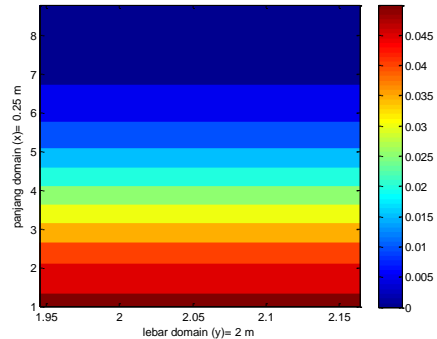

(g) Pada saat $t=140\left(5 \times 10^{-6}\right) \mathrm{s}$
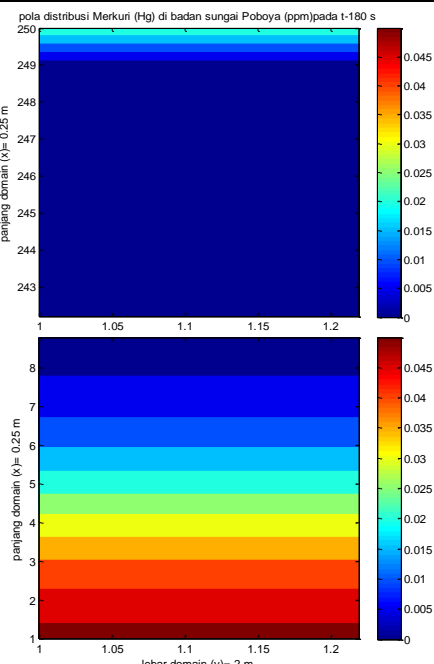

(i) Pada saat $t=180\left(5 \times 10^{-6}\right) \mathrm{s}$

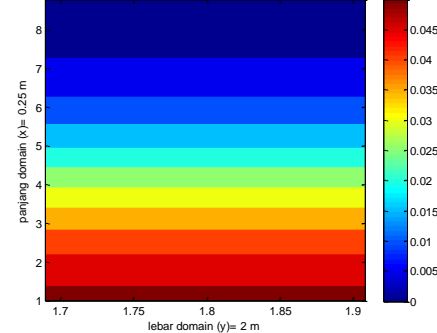

(h) Pada saat $t=160\left(5 \times 10^{-6}\right) \mathrm{s}$
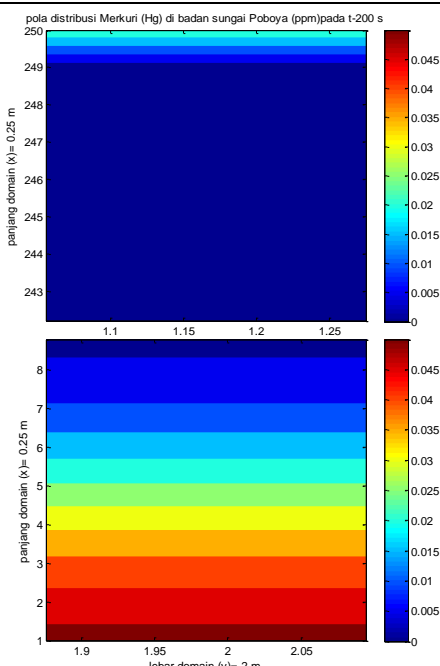

(j) Pada saat $t=200\left(5 \times 10^{-6}\right) \mathrm{s}$

Gambar 3 : Pola Distribusi Merkuri $(\mathrm{Hg})$ di Sedimen Sungai Poboya Sumber: Matlab R2010a

Tabel 1 : Jarak Merkuri Terdistribusi Pada Waktut $=20 \Delta t \mathrm{~s}$ Sampai $t=100 \Delta t \mathrm{~S}$

\begin{tabular}{|c|c|c|c|c|c|}
\hline Waktu (s) & $\begin{array}{l}\text { Jarak yang } \\
\text { dicapai oleh } \\
\text { distribusi } \\
\text { merkuri } \\
\text { pada waktu } \\
\text { tertentu dari } \\
(0, y) \quad \text { ke } \\
(250, y)(\mathrm{m})\end{array}$ & $\begin{array}{l}\text { Jarak yang } \\
\text { dicapai oleh } \\
\text { distribusi } \\
\text { merkuri pada } \\
\text { waktu } \\
\text { tertentu dari } \\
(250, y) \quad \text { ke } \\
(0, y)(\mathrm{m})\end{array}$ & Waktu (s) & $\begin{array}{l}\text { Jarak yang } \\
\text { dicapai oleh } \\
\text { distribusi } \\
\text { merkuri } \\
\text { pada waktu } \\
\text { tertentu dari } \\
(0, y) \quad \text { ke } \\
(250, y)\end{array}$ & $\begin{array}{l}\text { Jarak yang } \\
\text { dicapai oleh } \\
\text { distribusi } \\
\text { merkuri pada } \\
\text { waktu } \\
\text { tertentu dari } \\
(250, y) \quad \text { ke } \\
(0, y)\end{array}$ \\
\hline$t=20 \Delta t$ & $2,8501 \Delta x$ & $249,1784 \Delta x$ & $t=120 \Delta t$ & $6,1607 \Delta x$ & $249,131 \Delta x$ \\
\hline$t=40 \Delta t$ & $3,6879 \Delta x$ & $249,1588 \Delta x$ & $t=140 \Delta t$ & $6,732 \Delta x$ & $249,1292 \Delta x$ \\
\hline$t=60 \Delta t$ & $4,3765 \Delta x$ & $249,1465 \Delta x$ & $t=160 \Delta t$ & $7,2587 \Delta x$ & $249,1281 \Delta x$ \\
\hline$t=80 \Delta t$ & $4,9305 \Delta x$ & $249,1387 \Delta x$ & $t=180 \Delta t$ & $7,7963 \Delta x$ & $249,1274 \Delta x$ \\
\hline$t=100 \Delta t$ & $5,6144 \Delta x$ & $249,1339 \Delta x$ & $t=200 \Delta t$ & $8,3203 \Delta x$ & $249,127 \Delta x$ \\
\hline
\end{tabular}


Tabel 2 : Jarak yang Ditempuh oleh Distribusi Merkuri di Sedimen Sungai Poboya

\begin{tabular}{|c|c|c|c|}
\hline \multicolumn{2}{|c|}{$\begin{array}{l}\text { Selisih jarak yang dicapai oleh distribusi } \\
\text { merkuri pada waktu tertentu dari }(0, y) \text { ke } \\
(250, y)(\mathrm{m})\end{array}$} & \multicolumn{2}{|c|}{$\begin{array}{l}\text { Selisih Jarak yang dicapai oleh } \\
\text { distribusi merkuri pada waktu } \\
\text { tertentu dari }(250, y) \text { ke }(0, y)(\mathrm{m})\end{array}$} \\
\hline $\begin{array}{l}(t=40 \Delta t) \\
-(t=20 \Delta t)\end{array}$ & $\begin{array}{l}3,6879 \Delta x-2,8501 \Delta x= \\
0,0036879-0,0028501 \\
=0,0008378\end{array}$ & $\begin{array}{l}(t=40 \Delta t) \\
-(t=20 \Delta t)\end{array}$ & $\begin{array}{l}249,1588 \Delta x \\
-249,1784 \Delta x \\
=-0.0000196\end{array}$ \\
\hline $\begin{array}{l}(t=60 \Delta t) \\
-(t=40 \Delta t)\end{array}$ & $\begin{array}{l}4,3765 \Delta x-3,6879 \Delta x= \\
0,0043765-0,0036879 \\
=0,0006886\end{array}$ & $\begin{array}{l}(t=60 \Delta t) \\
-(t=40 \Delta t)\end{array}$ & $\begin{array}{l}249,1465 \Delta x \\
-249,1588 \Delta x \\
=-0,0000123\end{array}$ \\
\hline $\begin{array}{l}(t=80 \Delta t) \\
-(t=60 \Delta t)\end{array}$ & $\begin{array}{l}4,9305 \Delta x-4,3765 \Delta x= \\
0,0049305-0,0043765 \\
=0,000554\end{array}$ & $\begin{array}{l}(t=80 \Delta t) \\
-(t=60 \Delta t)\end{array}$ & $\begin{array}{l}249,1387 \Delta x \\
-249,1465 \Delta x \\
=-0,0000078\end{array}$ \\
\hline $\begin{array}{l}(t=100 \Delta t) \\
-(t=80 \Delta t)\end{array}$ & $\begin{array}{l}5,6144 \Delta x-4,9305 \Delta x= \\
0,0056144-0,0049305 \\
=0,0006839\end{array}$ & $\begin{array}{l}(t=100 \Delta t) \\
-(t=80 \Delta t)\end{array}$ & $\begin{array}{l}249,1339 \Delta x \\
-249,1387 \Delta x \\
=-0,0000048\end{array}$ \\
\hline $\begin{array}{l}(t=120 \Delta t) \\
-(t=100 \Delta t)\end{array}$ & $\begin{array}{l}6,1607 \Delta x-5,6144 \Delta x= \\
0,0061607-0,0056144 \\
=0,0005463\end{array}$ & $\begin{array}{l}(t=120 \Delta t) \\
-(t=100 \Delta t)\end{array}$ & $\begin{array}{l}249,131 \Delta x \\
-249,1339 \Delta x \\
=-0,0000029\end{array}$ \\
\hline $\begin{array}{l}(t=140 \Delta t) \\
-(t=120 \Delta t)\end{array}$ & $\begin{array}{l}6,732 \Delta x-6,1607 \Delta x= \\
0,006732-0,0061607 \\
=0,0005713\end{array}$ & $\begin{array}{l}(t=140 \Delta t) \\
-(t=120 \Delta t)\end{array}$ & $\begin{array}{l}249,1292 \Delta x \\
-249,131 \Delta x \\
=-0,0000018\end{array}$ \\
\hline $\begin{array}{l}(t=160 \Delta t) \\
-(t=140 \Delta t)\end{array}$ & $\begin{array}{l}7,2587 \Delta x-6,732 \Delta x= \\
0,0072587-0,006732 \\
=0,0005267\end{array}$ & $\begin{array}{l}(t=160 \Delta t) \\
-(t=140 \Delta t)\end{array}$ & $\begin{array}{l}249,1281 \Delta x \\
-249,1292 \Delta x \\
=-0,0000011\end{array}$ \\
\hline $\begin{array}{l}(t=180 \Delta t) \\
-(t=160 \Delta t)\end{array}$ & $\begin{array}{l}7,7963 \Delta x-7,2587 \Delta x= \\
0,0077963-0,0072587 \\
=0,0005376\end{array}$ & $\begin{array}{l}(t=180 \Delta t) \\
-(t=160 \Delta t)\end{array}$ & $\begin{array}{l}249,1274 \Delta x \\
-249,1281 \Delta x \\
=-0,0000007\end{array}$ \\
\hline $\begin{array}{l}(t=200 \Delta t) \\
-(t=180 \Delta t)\end{array}$ & $\begin{array}{l}8,3203 \Delta x-7,7963 \Delta x \\
=0,0083203 \\
-0,0077963=0,000524\end{array}$ & $\begin{array}{l}(t=200 \Delta t) \\
-(t=180 \Delta t)\end{array}$ & $\begin{array}{l}249,127 \Delta x \\
-249,1274 \Delta x \\
=-0,0000004\end{array}$ \\
\hline
\end{tabular}

\section{KESIMPULAN}

Perubahan distribusi merkuri di Sungai Poboya terhadap waktu memperlihatkan bahwa dari waktu ke waktu konsentrasi merkuri terus menyebar dengan konsentrasi yang semakin meningkat di tiap titiknya. Hingga dalam waktu yang lama akan menjadi steady (tidak ada lagi perubahan konsentrasi merkuri terhadap waktu). Konsentrasi merkuri dari batas atas (sumber aliran) domain pengamatan terdistribusi mengikuti arah aliran air (kearah muara) karena proses adveksi dan semakin berkurang seiring aliran karena proses difusi. Konsentrasi merkuri dari batas bawah (domain pengamatan) terdistribusi berlawanan arah aliran (tidak searah aliran) kearah hulu sungai karena proses difusi, namun jarak distribusi merkuri yang dicapai tiap waktu tidak sejauh yang dicapai distribusi merkuri dari sumber aliran tiap waktu karena adanya proses adveksi dan rendahnya konsentrasi merkuri. 


\section{DAFTAR PUSTAKA}

[1] Alman, Kusuma, J., dan Amiruddin, Penyelesaian Numerik Persamaan Adveksi Difusi 2-D untuk Transfer Polutan dengan Menggunakan Metode Beda Hingga Dufort Frankel, Jurnal Matematika, 1-14, 2013, (http://repository.unhas.ac.id/handle/123456789/1234 2).

[2] Fantozzi, L., Manca, G., and Sprovieri, F, A Comparison of Recent Methods for Modelling Mercury Fluxes at The Air-Water Interface, E3S Web of Conferences, 01, 2013.

[3] Habibi, Analisis Kelayakan Debit Andalan Sungai Poboya untuk Suplay Air Bersih Palu Timur, Skripsi,2010, (http://dokumen.tips/download/link/skripsi-habibi).

[4] Harian Kompas, Ketika Krisis Air di Depan Mata, Kompas, 2016, 22 Maret , (http://national geographic.co.id/berita/2016/03/ketika-krisis-air-di-depan-mata Diakses), diakses 11 Maret 2016.

[5] Herman, D. Z., Tinjauan terhadap Tailing Mengandung Unsur Pencemar Arsen (As), Merkuri $(\mathrm{Hg})$, Timbal $(\mathrm{Pb})$, dan Kadmium (Cd) dari Sisa Pengolahan Bijih Logam, Indonesian Journal on Geoscience, 1(1), 31-36, 2006.

[6] Mosey, H. I., Pemodelan Penyebaran Polutan di Udara dengan Solusi Persamaan Difusi Advektif, Jurnal IImiah Sains, 11(1), 58-60, 2011.

[7] Purnawan, S., Sikanna, R., \& Prismawiryanti, P., Distribusi Logam Merkuri pada Sedimen Laut di Sekitar Muara Sungai Poboya, Online Journal of Natural Science FMIPA, 2(1), 2013. 